\title{
The Role of Geomorphological Studies in Development of Coastal Cities
}

\author{
Maryam Valadkhani, Hamidreza Naderifar*, Ardavan Behzad \\ Department of Geography, Central Tehran Branch, Islamic Azad University, Tehran, Iran \\ Email:^hamidrezanaderifar@yahoo.com
}

How to cite this paper: Valadkhani, M., Naderifar, H. and Behzad, A. (2017) The Role of Geomorphological Studies in Development of Coastal Cities. Open Journal of Geology, 7, 768-777. https://doi.org/10.4236/ojg.2017.76051

Received: September 16, 2016

Accepted: June 4, 2017

Published: June 7, 2017

Copyright $\odot 2017$ by authors and Scientific Research Publishing Inc. This work is licensed under the Creative Commons Attribution International License (CC BY 4.0).

http://creativecommons.org/licenses/by/4.0/ (c) (i) Open Access

\begin{abstract}
Natural and unnatural factors would develop coastal areas. Coastal area is a region that takes materials and substances from land surface then transfers them to sea and the remained and cumulative substances of them would deform under the effect of erosion forming the coasts appearance. Geomorphology is the study of land and process leading to formation and development of it. Coastal geomorphology emphasizes on formation of coastal areas and some processes such as waves, tides, and stream leading to formation of boulders, coral reefs and sandy beaches. The base of this study is on analytical comparison method of affecting variables on periodic change of shoreline in river estuary in which statistical and image data were analyzed. This research was conducted within three time intervals including 1955-1988, 2000-2006, and 2006-2013. Wind hourly data of Meteorological Organization of Iran was used to study waves. The fluctuation in level of Caspian Sea is an important factor in changes in shoreline of Caspian Sea besides the role of river and providing sediment output into the sea. The most area was belonged to 1995 along with declining trend of seal level of Caspian Sea and the lowest area was belonged to 2000 with a rising trend of sea level within three studied intervals. This point indicates the effect of seal level factor on change in area of studied intervals.
\end{abstract}

\section{Keywords}

Geomorphological Studies, Development of Coastal Cities

\section{Introduction}

The world shorelines indicate one of the most active natural environments. Shorelines would make unique and extraordinary processes close to each other that not only comprise sea processes but also include the processes resulted by transmission of water and sediments of rivers to the sea [1] [2]. This research 
investigates the change of the velocity on seawall crown by considering the obstacles in different layouts and slopes [3] [4]. It required recognizing features of coastal areas and their stability for any planning for establishment of human activities and exploiting from capacities of coastal areas because recognition of geomorphological conditions of coast would form the base of every research in field of coastal areas [5] [6]. Compound section is referred to a section the surface of which is made of several sub-sections with different flow characteristics [7] [8].

Geomorphology is one of the branches of natural geography and a basic axis of geographical sciences linked to other natural and earth sciences. Geomorphology consists of three words of geo that means Earth, morph that means the form, and logy that means identification. It seems that the landform science, the Persian equivalent of geomorphology is more appropriate than the title of identification of land body used before or morphology using now for translation of this term to Persian. Hydraulics creates an interaction between the main channel and floodplains, resulting in an apparent shear stress and a transverse momentum transfer [9] [10]. Apparently, what is understood from the combined term of geomorphology is description of geometric shape of the ruggedness of the Earth's crust that comprises topography which is the branch of geomorphology. The intended slopes for seawalls were 22, 27, 32, 39 degrees, respectively and had the roughness heights on wall surface which were $15 \mathrm{~cm}, 20 \mathrm{~cm}$ and $30 \mathrm{~cm}$. Moreover, four types of roughness layouts on the wall surface were investigated [11] [12] [13]. In summary, the knowledge territory of geomorphology not only includes correct and perfect description of genetic ruggedness's shapes but also determines the effective factors, qualities and origins in changing shapes or new formation of Earth's crust. Breakwaters are structures which are constructed in order to create peace in a pool of ports, to prevent port erosion, and to protect the shipping channel [14] [15] [16]. The purpose of analysis of geomorphology term is not just definition of this science but the important point is to become familiar with concept, method, and methodology of this knowledge that every researcher of Earth's science should completely know it.

\section{Research Background}

There have been many conducted studies in world and regions due to importance of the subject [8]. Compared different methods for evaluation of changes in shoreline in different areas of the world found that three methods including WLS, RWLS, and WLAD are more prior among statistical methods [9]. Predicted changes rate equal to $1 / 13$ meter per year using numerical method based on geomorphological and geological features, historical evidences and fluctuations of sea level in shoreline of Accra in Gulf of Guinea [10]. Predicted shoreline changes in Puri Coast in Bay of Bengal, India using ending point amount method and field observation for 2015 and 2025 [17]. Used linear regression and endpoint rate to predict changing rates of shoreline of Erie Lake, Canada concluded that human activities might change the predictive results. The lack of research in field of predicting shoreline changes in Oran is a problem [12]. Carried 
out two separate studies in field of prediction of change rate in shoreline of Chabahar Region and Pejam Gulf examining the position of shoreline using satellite data. These researchers benefited from endpoint rate, least squares and combined method to predict shoreline believing that use of combined method has had better results compared to other statistical methods. Majority of studies in area of shoreline of Gorgan Rood have emphasized on effecting factors on Delta from landside or effect of sea level fluctuation less considering changes in shoreline. Some of these studies are as follows: conducted study by [6] examining geomorphological evidences of changes in Caspian Sea level during Late Quaternaryin area of Gorgan Rood River, study by [7] investigating some observations of seal level of Caspian Sea in central part of Gilan, east of Mazandaran, and study of kakroodi et al. examining rapid changes in sea level of Caspian Sea during Holocene in east south of Caspian Sea emphasizing on sea level fluctuation.

\section{Research Methodology}

The base of this study is on analytical comparison method of affecting variables on periodic change of shoreline in river estuary in which statistical and image data were analyzed. Apparent shear stress and transverse momentum transfer resulted from it play important roles in the calculation of flow rate and secondary flows to identify and control the sediment transport mechanism in order for protecting coasts, organizing rivers, designing a stable channel, analyzing scouring as well as transmitting the contamination [4]. Wind hourly data of Meteorological Organization of Iran was used to study waves. This research was conducted within three time intervals including 1955-1988, 2000-2006, and 20062013. To study the water discharge status and estimation of sediment of rivers, the statistics (monthly and yearly) of water flow and sediment of rivers were prepared from Iran Water Resources Management Company. Characteristics of waves such as height, period, length, and frequency of wave were calculated from data of 55-year winds of Synoptic Station of Babolsar (1951-2006) using Coastal Protection Regulations. In this method, fetch length, wind tension factor, 10-meter levels of wind speed, spatial effects, stability correction and average wind speed during the obtained wind blowing, and finally prediction of waves resulted from wind were calculated for wind data of Babolsar Station (Yamani et al., 2010). Data of statistical period of 1929-2013 of Ports and Maritime Organization in Anzali Station were used for level gauging of seawater to assess daily, monthly, quarterly, and yearly changes. Illustration and digitalization of topography maps, aerial photographs and satellite imagery was done through ArcGIS Software. Preprocess, process and detection of multi-temporal satellite images from studied area was done using Excel Software and to illustrate wind rose, WRPOLT Software was used and to illustrate wave rose, MIKE21 Software was used. The method of 2 equidistant profiles has been used in this study to determine changes in shoreline and recognizing the nature, place, and occurrence time of changes in shoreline. To illustrate the mentioned profiles at the part of coastal hinterland, a direct line was illustrated as baseline in order to assess the 
digitalized images and data toward this fix line. Then, the studied area was divided to three separated intervals with emphasize on estuary of rivers Haraz, Babolrood and Talar so that each interval transversal cutters with determined 500 -meter distances and then the aerial image in 1956, satellite images in 1988, 2000, and 2006 as well as the image of Spot satellite in 2013 were used through Google Earth Software to identify changes rate in shoreline. Process and detection of images was done through ENVI Software due to more than $60 \mathrm{~km}$ length of coastline and for overlapping of satellite images and mosaic of pictures. The images of visible and near-infrared bands were entered to ArcGIS after processing in ENVI and images and maps were digitalized. Finally, the positive and negative rate of changes of shoreline in area of estuary of the river was assessed and analyzed during different years through overlapping and combining digitalized images and maps with equidistant profiles.

\section{The Area of Studied Region}

The studied area is located in southern part of Caspian Sea at estuary of rivers Haraz, Babolrood, and Talar like a thin area from Fereydoon Kenar to Bahmanmir within geographical coordinates $52^{\circ} 25^{\prime}$ to $52^{\circ} 46^{\prime}$ of east longitude and north latitude $36^{\circ} 40^{\prime}$ to $36^{\circ} 43^{\prime}$. Hazar, Bolbolrood and Talar Rivers are originated from Alborz Mountains passing though meander mountain paths, respectively spilling into alluvial fans Amol, Babol and Ghaemshahr and eventually into the Caspian Sea.

\section{Findings and Results}

Digitalization of aerial image in 1995 and satellite images during 1988-2013 with extraction of shorelines in model of equidistant profiles between baseline and multi-temporal shorelines indicates many changes in geometry of shoreline and estuary of studied rivers.

The longest length of shoreline of Sorkhrood reach has been calculated equal to 5077 meters in 1955 and 1988 and the lowest length of shoreline equal to 4571 meters in 2006. The highest area of Sorkhrood is equal to $5 \mathrm{~km}^{2}$ in 1955 and lowest area is equal to $1 / 6 \mathrm{~km}^{2}$ in 2000 indicating high rate changes in shoreline in Sorkhrood reach but the longest shoreline of Babolrood reach is equal to 5302 meters in 2006 and the shortest shoreline is equal to 5049 meters in 2000. The most total area of Babolrood was equal to $2 / 3 \mathrm{~km}^{2}$ in 1955 and the lowest area was equal to $1 / 8 \mathrm{~km}^{2}$ in 2000 . At the studied easternmost (Talar reach), the maximum length of shoreline was equal to 5126 meters in 1988 and the minimum length was equal to 5034 meters in 2006. The maximum area of Talar reach was equal to $2 / 2 \mathrm{~km}^{2}$ in 2006 and the minimum area of this reach was equal to $1 / 8 \mathrm{~km}^{2}$ in 2000 . The considerable point in calculation of area and length of shoreline during studied years is that the difference between minimum and maximum of total area has been less in three Talar, Babolrood, and Haraz reaches averagely equal to $0 / 6 \mathrm{~km}^{2}$, but the difference between maximum and minimum of the length of shoreline is very high so that changing domain in Ta- 
lar reach is equal to 92 meters, in Babolrood reach equal to 141 meters, and Sorkhrood reach equal to 506 meters (Table 1).

Survey measurement and calculation of average slope of coastal area in unit one of Srokhrood reach toward unit ten of interval from $0 / 15$ to $0 / 1$ percent indicates the gradual decrease the average slope of studied reaches in the direction of West to the East. Decrease in slope of area from Sorkhrood to Talar is an effective factor in increase in transgressions and regressions areas of studied region toward east. In addition to the slope rate of reaches, the increasing trend of transgression and regression rates toward east has not followed the direct linear pattern since 1955 so far due to consuming changes inside and outside of the 60-meter space of Caspian Sea. According to the transgression and regression of studied intervals indicates that the most rate of sea transgression toward land in reach of Sorkhrood related to period of $1988-2000$ is equal to $634,878 \mathrm{~m}^{2}$ and the most area of sea regression in this reach is equal to $86,857 \mathrm{~m}^{2}$ during 1988-2000. The most rate of sea transgression toward land in reach of Babolrood related to period of $1988-2000$ is equal to $581,585 \mathrm{~m}^{2}$ and the most area of sea regression in this reach is equal to $307,306 \mathrm{~m}^{2}$ during $2000-2006$. The most rate of sea transgression toward land in reach of Talar related to period of 1988-2000 is equal to $581,585 \mathrm{~m}^{2}$ and the most area of sea regression in this reach is equal to $59,905 \mathrm{~m}^{2}$ during 2000-2006.

There is a close relation between shoreline transgression and regression with ascending and descending trend of Caspian Sea level. The continuity of descending trend during 1929-1977 has changed the sea level from $-25 / 30$ to $-28 / 64$ in 1977 [8]. Sea regression and increase in land area in 1955 occurred due to this descending trend of seal level. The ascending trend and increase in sea level occurred during 1978-1995 so that the sea level increased from -28/64 in 1977 to $-26 / 08$ indicating $22 / 30$ meter increase in sea level height during 18 years (Researches and Studies center of Water Resources of Caspian Sea, 2000). According to the conducted calculations in model of equidistant profiles, the most sea transgression and flooded coats has been recorded during 1988-2000 through increasing trend of sea level. The descending trend and sea regression has been started since 1995 with decrease in sea level so that a $5 \mathrm{~cm}$ height decrease in 2008 and 2013 has been respectively equal to $-26 / 47$ and $-26 / 56$ (Figure 1).

The area between shorelines indicates that the most sea transgression and in-

Table 1. Area and length of shoreline of three studied reaches during 1955-2013.

\begin{tabular}{|c|c|c|c|c|c|c|}
\hline \multicolumn{2}{|c|}{ Talar reach } & \multicolumn{2}{|c|}{ Bolbolrood reach } & \multicolumn{3}{|c|}{ Sorkhrood reach } \\
\hline Total area ${ }^{*}$ & Length of shoreline & Total area & Length of shoreline & Total area & Length of shoreline & Year \\
\hline $2,125,681$ & 5115 & $2,310,226$ & 5160 & $2,578,031$ & 5077 & 1955 \\
\hline $2,037,632$ & 5126 & $2,256,340$ & 5190 & $2,513,009$ & 5077 & 1988 \\
\hline $1,830,755$ & 5056 & $1,842,322$ & 5049 & $1,672,734$ & 5160 & 2000 \\
\hline $2,209,416$ & 5034 & $1,925,135$ & 5302 & $1,928,812$ & 4571 & 2006 \\
\hline $1,982,334$ & 5103 & $1,965,784$ & 5159 & $2,024,018$ & 4618 & 2013 \\
\hline
\end{tabular}

*The calculation base is the area under the curve between shoreline and baseline and its unit is $\mathrm{m}^{2}$. 
crease in coastal area is recorded for 2000-2006 with descending trend of sea level. Analysis of image data emphasizing on seawater transgression or regression can explain many of changes in shorelines in past. A review of annual statistics of fluctuation in Caspian Sea level indicates that transgression and regression in studied reaches is only influenced by fluctuations of seawater so that the most transgression has been occurred during 1987-2000 and the most regression occurred during 2000-2006. The most area of studied reaches was related to 1995 (descending period of sea level) and the lowest areal was related to 2000 (increasing trend of sea level) indicating interference of the sea level factor in changing area of studied years (Figure 2). However, study of the most and the lowest length of shoreline in three mentioned reaches does not indicate similar annual distribution. This point indicates the interference of various variables with changes in coastal area and line. In other words, the area of reaches is directly related to fluctuation of seawater but changes in shoreline in three mentioned reaches indicate the effect of other determining variables (Figure 2).

In accordance with $60-\mathrm{km}$ distance between shoreline of Sorkhrood reach and Talar and non-uniform waves in three reaches, distinguish of the relation of shoreline changes is not separately confirmed within three reaches with dynamic of waves. On the other hand, the role of fluctuation of seawater and dynamic of waves in high changes of shorelines during 1955-2013 is not deniable. Hence, the statistics of 55-year wind of synoptic station of Babolsar (1951-2006) was used to

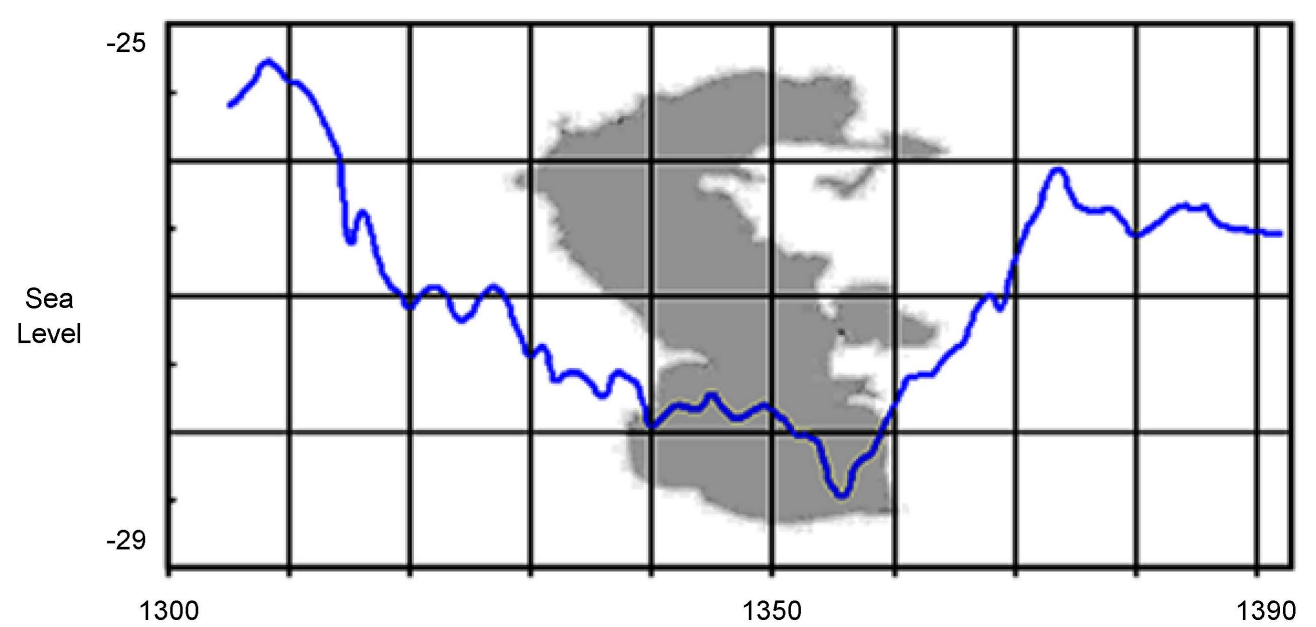

Figure 1. Fluctuation of Caspian Sea level in level gauging station of Anzali during 1929-2013.

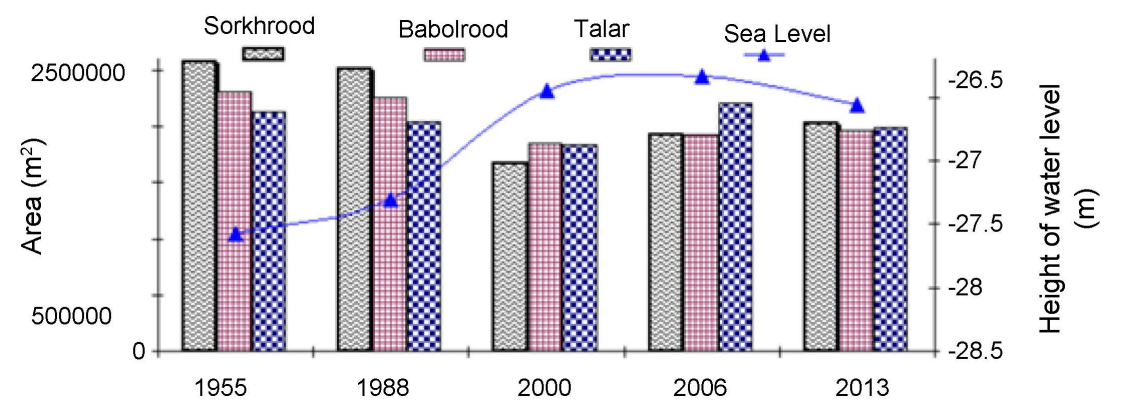

Figure 2. Relation between area of reaches and sea level. 
study the waves raised from wind. According to the mentioned data of dominant wind of west region blowing for 8 months of year with average 6.3 knots from this direction. The direction of dominant wind is northwest during May and June blowing with 5.6 knots speed averagely. It is only in January that direction of dominant wind is northeast reported with an approximate speed of 7.5 knots (Figure 3). According to the wind data and correction of its data using coefficients of Shore Protection Manual (SPM), the waves raised from wind have been predicted and finally the wave roses of waves raised from wind have been illustrated in Babolsar Station. The waves raised form wind in shallow waters with height from 0 to more than $2 / 5$ meters indicates the frequency of $46.2 \%$ occurrence. The occurrence rate of calm waves is equal to $53 / 8 \%$ during statistical period of 1951-2005. The most frequency of waves in shallow waters in terms of importance is respectively from northwest and northeast. The direction of waves, raised from wind blowing from quadrant of west north includes $17.2 \%$ of waves' frequency and the height of these waves is more than 2.5 meters. After this level, the largest number of waves is reported from the east north sector toward shorelines. The maximum of waves' height is equal to 2.5 meters and frequency of recorded waves from direction of east north is equal to $9.6 \%$.

Study of illustrated equidistant profiles in ten units of research reaches indicates that fluctuation of changes through shoreline and the area of units is usually in middle parts of river reaches from west toward east of river estuary that is coordinated with dominant direction from west north and lateral run of sediment toward east.

In addition to the mentioned variables from seaside can affect changes in shoreline, study of flow and estimation of sediment of stations of Sorkhrood, Miandasht, and Kiakola that are the closest stations to estuary of rivers Haraz, Babolrood and Talar can determine the role of rivers in changes rate of shoreline. Among research reaches, the most recorder flow and output sediment is respectively belonged to reach of Babolrood and Talar Rivers. The average of monthly flow in Miandasht Station of Babolrood has been measured to 14/8 $\mathrm{m}^{3} / \mathrm{s}$ with annual sediment equal to 493,312 thousand tons per year and the measured average of sediment in three cross-sections (CM) equal to $1273 \mathrm{mg} / \mathrm{l}$ indicates the most annual flow and sediment in whole of three reaches. The average of monthly flow in Kiakola Station of Talar River has been measured to

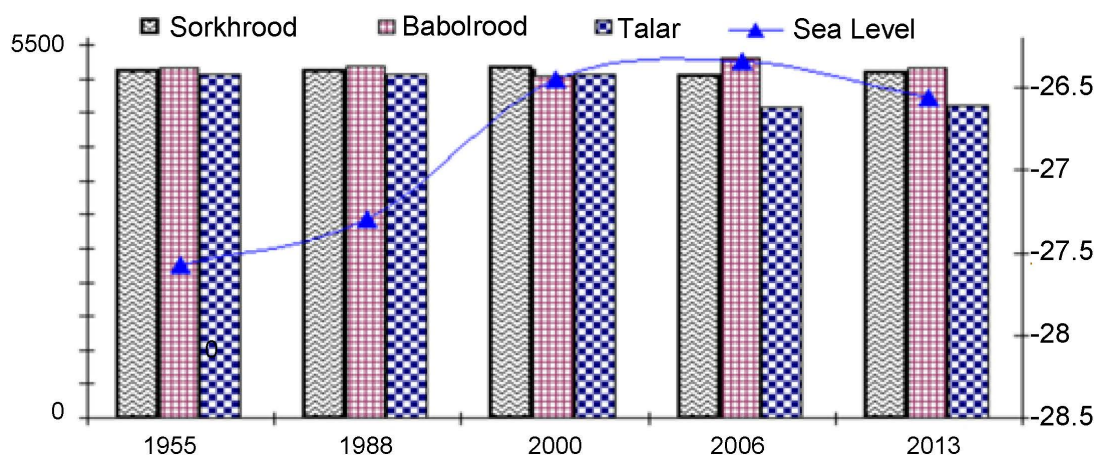

Figure 3. Relation between length of shoreline and sea level. 
$9.1 \mathrm{~m}^{3} / \mathrm{s}$ with annual sediment equal to 352,368 thousand tons per year and the measured average of sediment in three cross-sections (CM) equal to $1698 \mathrm{mg} / \mathrm{l}$ is at the second rank in terms of flow rate and input sediment into sea. The lowest rate of flow and sediment is belonged to reach of Sorkhrood River with average monthly flow of $6.7 \mathrm{~m}^{3} / \mathrm{s}$ and average annual sediment equal to 43,642 thousand tons as well as the average sediment equal to $522 \mathrm{mg}$ per liter within three measured cross sections (Figure 4).

According to examination of ten units of research reaches in equal illustrated profiles indicates an increase in land area during 2000-2006 and 2007-2013 (Figure 5). Decrease in sea level during this period has been the main factor of epeirogenic incident and increase in area of units, but the considerable point is the relation between fluctuation of seawater level and change percent of land level has not been led to increase in area of reaches thorough a similar trend during periods of decreasing sea level. In other words, the role of entering sediment of river to the sea in trend of increasing the area of reaches can be considered in addition to the fluctuation of seawater. Unbalanced trend in changes percent of reaches' area during different periods indicates the effect of the factor of output sediment of rivers for sea besides the main role if fluctuation of sea

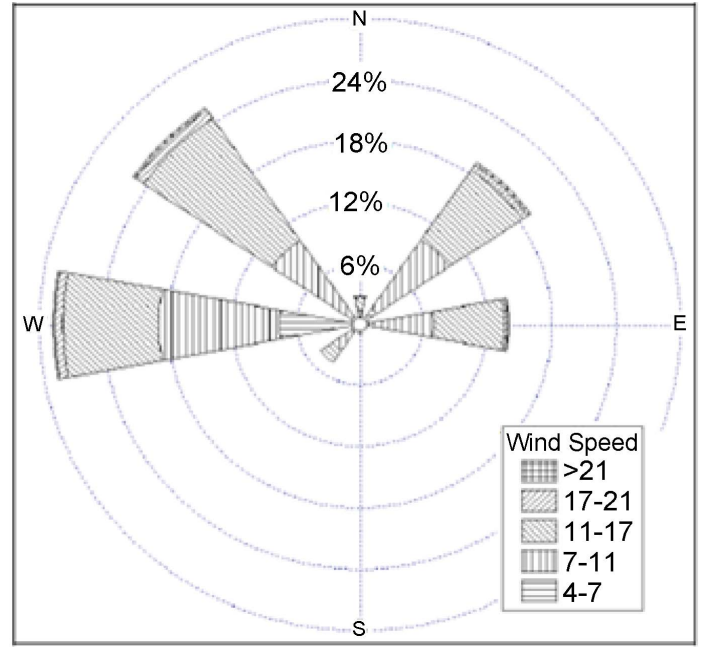

Figure 4. Wind rose of annual wind of synoptic station of Babolsar based on knot (1951-2006).

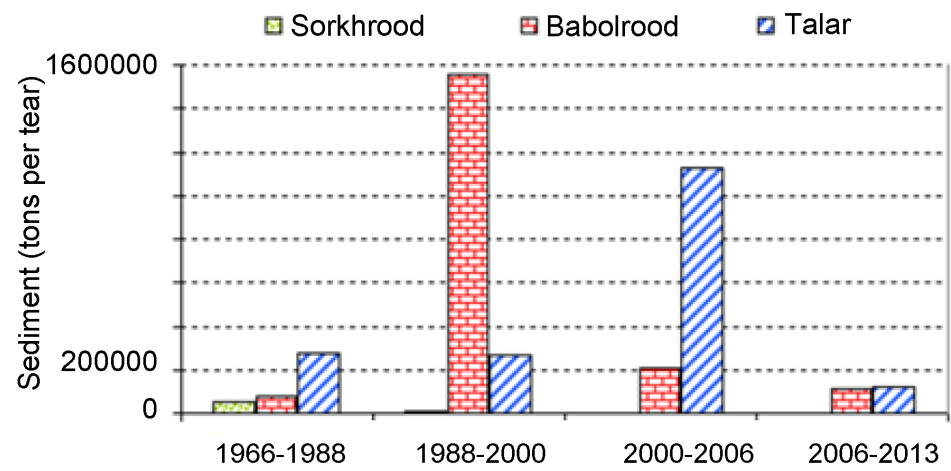

Figure 5. Sediment rate of sediment assessing stations during 1955-2013. 
level in creation of positive and negative changes. Study of the multi-temporal equidistant profiles indicates that maximum changes are in middle units. On the other hand, more changes can be seen in eastern units of river estuary compared to western symmetry. These changes are usually emerge as increase in area of eastern units of river estuary in units $6-10$ of Sorkhrood, Babolrood, and Talar reaches that are coordinated with dominant direction of waves from north west and lateral rift of sediment toward east along shoreline. The waves that are raised from wind along with long waves in shallow areas near to shoreline with direction of west north and east north would lead to lateral drift of sediment from west to east and reverse that finally lead to general drift of sediment toward east due to upper height and more frequency of waves from west north direction so that this case leads to increase in area of eastern units of estuary compared to west symmetry.

\section{Conclusion}

Geomorphology has a specific priority because of its ability to provide and direct required preparations to be used in expensive methods such as recognition catheters that are common in geophysics. In this regard, application of geophysics methods and recognition catheters requires heavy costs. Using geomorphology methods, appropriate places can be chosen in which, the successful chance of use of these methods is more. In this case, the waste of heavy costs in implementation of geophysics methods is prevented. It was concluded in this study that fluctuation of Caspian Sea level is an important factor in shoreline changes in Caspian Sea while the role of river and its output sediment to sea are not deniable. The most area in all three studied reaches was occurred in 1955 with a descending trend of Caspian Sea level and the lowest area was occurred in 2000 with an ascending trend of sea level indicating interference of sea level factor in area changes of studied reaches. Analysis of illustrated profiles indicates heterogeneous changes through reaches especially in middle units of reaches, river estuary and its surrounding area. Existence of maximum level of change around the estuary of Talar, Babolrood, and Haraz Rivers besides key role of fluctuation in seawater emphasizes on effective role of output sediment of rivers to Caspian Sea.

\section{References}

[1] Azarmsa, A. and Razmkhah, F. (2010) Prediction of Position and Changes of Shoreline in Pejam Gulf until 2010. Physics of the Earth and the Sea, No. 4, 89-98.

[2] Jafar Beigloo, M., Zaman Zadeh, M., Yamani, M. and Imad al-Din, S. (2012) Geomorphological Evidences on the Caspian Sea Level Changes during the Late Quaternary in Gorgan-Rud River Area. Physical Geography Studies, No. 2, 33-50.

[3] Deilami-Tarifi, M., Behdarvandi-Askar, M., Chegini, V. and Haghighi-Pour, S. (2016) Modeling of the Changes in Flow Velocity on Seawalls under Different Conditions Using FLOW-3D Software. Open Journal of Marine Science, 6, 317-322. https://doi.org/10.4236/ojms.2016.62026

[4] Yamani, M., Moghimi, A., Motamed, A., Jafar Beigloo, M. and Lorestani, Gh. (2013) 
Study of the Rapidly Shoreline Changing of Using Analysis Method of Equidistant Profile. Physical Geography Research, No. 2, 1-20.

[5] Ebrahimi, A., Askar, M.B., Pour, S.H. and Chegini, V. (2015) Investigation of Various Random Wave Run-Up Amounts under the Influence of Different Slopes and Roughnesses. Environment Conservation Journal, 16, 301-308.

[6] Lahijani, H.A.K., Rahim-pour-Bonab, H., Tavakoli, V. and Hosseindoost, M. (2009) Evidence for Late Holocene High Stands in Central Guilan-East Mazanderan, South Caspian Coast, Iran. Quaternary International. 197, 55-71. https://doi.org/10.1016/j.quaint.2007.10.005

[7] Mifoor, I., Askar, M.B. and Pour, S.H. (2016) On the Investigation of Basic Parameters of Designing Protective Layer of the Offshore Breakwaters at Iran's Kharg Island. International Journal of Recent Scientific Research, 7, 98219823.

[8] Mukhopadhyay, A., Mukherjee, S., Mukherjee, S., Ghosh, S., Hazra, S. and Mitra, D. (2012) Automatic Shoreline Detection and Future Prediction: A Case Study on Puri Coast, Bay of Bengal, India. European Journal of Remote Sensing, 45, 201-213. https://doi.org/10.5721/EuJRS20124519

[9] Ario Cook, J. and Dourcamp, C. (1999) Geomorphology and Environmental Management, Vol. 2, Translation: Shahpur Goudarzi Nejad, Tehran, SAMT.

[10] Azarmsa, A. and Razmkhah, F. (2006) Study of Coastline Position in Chabahar Bay Using Satellite Data. Earth Sciences, No. 60, 25-32.

[11] Yamani, M., Lorestani, Gh. and Imad Al-Din, S. (2010) Dynamic Relation of Waves and Sand Distribution Directions Caspian Seaboard (the Area Babolrood and Haraz Rivers). Earth Science Research, Winter 1, 65-82.

[12] Bahadori, S. and Askar, M.B. (2016) Investigating the Effect of Relative Depth and Relative Roughness on Momentum Transfer in Symmetric Rectangular Compound Channels with Varius Relative Width. International Journal of Hydraulic Engineering, 5, 1-8.

[13] Appeaningaddo, K., Walkden, M. and Millsa, J.P. (2008) Detection, Measurement and Prediction of Shoreline Regression in Accra, Ghana. ISPRS Journal of Photogrammetry and Remote Sensing, 63, 543-558. https://doi.org/10.1016/j.isprsjprs.2008.04.001

[14] Kakroodi, A.A., Kroonenberg, S.B., Hoogendoorn, R.M., Mohamah Khani, H., Yamani, M., Ghassemi, M.R. and Lahijani, H.A.K. (2012) Rapid Holocene Sea-Level Changes along the Iranian Caspian Coast. Quaternary International, 263, 93-103. https://doi.org/10.1016/j.quaint.2011.12.021

[15] Bahadori, S. and Askar, M.B. (2016) Investigating the Simultaneous Effect of Relative Width and Relative Roughness on Apparent Shear Stress in Symmetric Compound Rectangular Channels. Journal of Current Research in Science, S(1), 654660.

[16] BaMasoud, A. and Louise Byrne, L. (2013) The Predictive Accuracy of Shoreline Change Rate Methods in Point Pelee, Canada. Journal of Great Lakes Research, 39, 173-181. https://doi.org/10.1016/j.jglr.2012.12.010

[17] Bahadori, S. and Askar, M.B. (2016) Investigating the Effect of Relative Width on Momentum Transfer between Main Channel and Floodplain in Rough Rectangular Compound Channel Sunder Varius Relative Depth Condition. Open Journal of Geology, 6, 225-231. https://doi.org/10.4236/ojg.2016.64020 
Submit or recommend next manuscript to SCIRP and we will provide best service for you:

Accepting pre-submission inquiries through Email, Facebook, LinkedIn, Twitter, etc. A wide selection of journals (inclusive of 9 subjects, more than 200 journals)

Providing 24-hour high-quality service

User-friendly online submission system

Fair and swift peer-review system

Efficient typesetting and proofreading procedure

Display of the result of downloads and visits, as well as the number of cited articles Maximum dissemination of your research work

Submit your manuscript at: http://papersubmission.scirp.org/

Or contact ojg@scirp.org 